\title{
The Role Of Patience Disposition On The Effect Of Self-Efficacy On Academic Cheating
}

\author{
Fahrul Rozi \\ Universitas Muhammadiyah Prof.Dr.HAMKA \\ Corresponding Author: fahrul.uhamka@gmail.com
}

\begin{abstract}
This research aims to determine the role of the disposition of patience on the effect of self-efficacy on academic cheating. Participants involved in this study were 340 people with $38 \%$ women (mean age of all subjects $=19.3$ and $\mathrm{SD}=2.01$ ). The measuring instrument used to measure the self-efficacy variable is the General Self Efficacy Scale (Schwarzer \& Jerusalem, 1995), the patience variable is measured by the First version of the Patience Scale (El Hafiz Lila, Rozi, Ilham, 2013), and the academic cheating variable is measured by the Academic Dishonesty Scale (Bashir \& Bala, 2018). The statistical analysis used in this study is the moderating analysis of Process Hayes (2013) which provides an overview of the role of the disposition of patience on the effect of self-efficacy on academic cheating. The disposition of patience will strengthen the negative effect of self-efficacy on academic cheating. The results show that patience acts as a significant moderating variable on the effect of self-efficacy on academic cheating and the disposition of patience strengthens the negative effect between these variables. Where, the negative effect on the effect of self-efficacy on academic cheating depends on the disposition of the level of patience. The higher the disposition of patience, the higher the negative effect of self-efficacy on academic cheating.
\end{abstract}

Keywords: Patience, Self Efficacy, Academic Cheating

\begin{tabular}{|c|c|c|c|c|}
\hline Submission & Review Process & Revised & Accepted & Published \\
\hline April 17, 2020 & $\begin{array}{c}\text { April 18, 2020- } \\
\text { May 15, 2021 }\end{array}$ & May 31, 2021 & June 3, 2021 & June 30, 2021 \\
\hline
\end{tabular}

\section{Introduction}

Cases of cheating in the academic field are quite worrying. At the Computer-Based National Examination (UNBK) on 2019, it was reported that 126 High School (SMA) students were included in the list of cases of cheating on the examination by sharing photos of questions and answer keys via smartphones. Provinces in Indonesia with the most cases of UNBK cheating came from East Java with 21 cases, South Kalimantan Province with 18 cases, Bali Province with 15 cases, West Java Province with 13 cases, and Lampung province with 13 cases (Alfons, 2019). Cheating behavior shown by someone and occurs in the world of education is often referred to as academic cheating.

There are several factors that cause academic cheating behavior, including; teachers or lecturers do not care about cheating behavior carried out by students, irrelevant exam material and peer pressure (Iberahim, Hussein, Samat, Noordin \& Daud, 2013). Various ethnicities, demographics of research subjects and gender also play a role in the forming of academic cheating behavior (Henning, Malpas, Manalo, Ram, Vijayakumar, Hawken, 2014). In a metaanalysis study, it shows that the big five personalities have an influence on the formation of academic cheating behavior. Individuals who tend having neurotic, extraverted, open to experience, easy to give approval and conformity will easily be motivated to commit academic cheating (Giluk $\&$ Postlethwaite, 2015). Interestingly, research shows that students who have achieved high achievement also support cheating behavior in the academic field (Miller, Murdock \& Grotewiel, 2017). 
Researches have explained that the development of scientific findings about academic cheating includes various aspects of studies and approaches in understanding the variables associated with cheating behavior. Biological, socio-cultural and psychological approaches provide a comprehensive understanding of the factors that shape academic cheating behavior. A biological approach that attempts to explain the relationship between heart rhythm and academic cheating behavior. A stable heart rate (resting) has a negative association with academic cheating, when an individual commits academic cheating it will further trigger the heart rate (Portnoy, Legee, Choy, Rudo-Hut, 2019). In the socio-cultural context, research results contribute to the development of strategic interventions in reducing academic cheating behavior, one of which is by useful and honest communication between teachers and students so that academic integrity can be improved (Pan, Stiles, Tempelmeyer \& Wong, 2019). While in the context of psychology, personality traits have an involvement with the formation of academic cheating (Giluk \& Postlethwaite, 2015). A person's personality traits, including internal self, are suspected to have a close involvement with academic cheating (Bacon, McDaid, William \& Corr, 2019). personality traits have an involvement with the formation of academic cheating (Giluk \& Postlethwaite, 2015). A person's personality traits, including internal self, are suspected to have a close involvement with academic cheating (Bacon, McDaid, William \& Corr, 2019). personality traits have an involvement with the formation of academic cheating (Giluk \& Postlethwaite, 2015). A person's personality traits, including internal self, are suspected to have a close involvement with academic cheating (Bacon, McDaid, William \& Corr, 2019).

Research related to internal self, one of which is self-efficacy, shows that academic cheating can be suppressed by this variable (Fida, Tramontano, Pacielo, Barbaranelli, 2018; Murdock \& Anderman, 2016). The findings of the cross-lagged model confirm that self-efficacy has the opposite effect on cheating behavior. In other words, selfefficacy negatively affects in an effort to reduce the tendency of academic cheating behavior. This is supported by research that proves that self-efficacy regulation can suppress the emergence of academic cheating behavior in students (Fida, Tramontano, Pacielo, Barbaranelli, 2018). Not only as a factor suppressing the emergence of cheating behavior, self efficacy has a role as moderator on academic goals on cheating behavior (Murdock \& Anderman, 2016).

Self-efficacy relates to individuals' beliefs about their abilities to influence events that can have an effect on their lives. Selfefficacy can be formed with the experience of mastery, social modeling, social persuasion and individual physiological strengths (Bandura, 2010). Self-efficacy can be formed from cognitive control and the ability to cope with behaviors that have high and low levels (Schwarzer, 2014). High cognitive control will reframe the thoughts of individuals who experience stress and sadness. While low cognitive control will drag the individual dissolved in the situation. Similarly, an individual's perceived ability to cope with stressful and sad situations depends on the individual's cognitive control at a high or low level. if high, the individual can choose to leave it or feel confident that he can change his behavior. If it is low, the individual will feel that the situation is unavoidable and less attractive to apply alternative solutions to get out of the situation.

In the context of education, selfefficacy has an influence on the formation of motivation, learning effects, self-regulation and academic achievement (Schunk\& Dibenedetto, 2016). With the forming of 
motivation that comes from self-efficacy, individuals will be encouraged to persevere when facing obstacles and obstacles and have resilience when facing difficulties. This motivation and resilience will give the spirit to keep learning and strive to self-regulate to get the best achievement. Therefore, when individuals have high self-efficacy, they are predicted to have a great opportunity to get the best achievement (Fast et al, 2010)

Individuals who have strong selfefficacy will see difficulties as challenges that can be overcome (Schunk\& Dibenedetto, 2016). They set challenging goals, stick to their commitments, seek to increase their efforts when faced with failure and recover quickly when setbacks occur. Efforts in achieving goals, commitment and persistent effort, will strengthen individuals to achieve goals without cheating, more specifically in the academic context (academic cheating).

Researches related to the factors that encourage the emergence of academic cheating behavior only explains the effects of social interaction, demographics, personality and academic achievement (Pan, Stiles, Tempelmeyer \& Wong, 2019;Giluk \& Postlethwaite, 2015; Miller, Murdock \& Grotewiel, 2017; Henning, Malpas, Manalo, Ram, Vijayakumar, Hawken, 2014). Recent research has not touched on religious values that can suppress academic cheating behavior, one of the religious values that are often used in daily life that can prevent the emergence of negative behavior and positive life achievements is patience (Schnitker, Houltberg, Dyrness, \& Redmond, 2017). Moreover, in recent research, the role of minimal patience is used to determine the strength of the relationship between variables related to academic cheating behavior. Patience is thought to be a virtue that functions to control the strength of the influence of selfefficacy on academic cheating.
Patient behavior will direct individuals in an ongoing effort to find solutions (El Hafiz, Lila, Rozi, Ilham, 2015) in order to achieve expectations so as to allow individuals to train themselves in managing various available resources to face and recover from stress (Iacoviello \& Charney, 2020). This will encourage individuals to continue to develop their potential and abilities in facing with various stressful situations throughout their lives.

Patience comes from Arabic, namely shabara. The word shabara cannot stand alone so it is necessary to add a complete word to become shabara 'ala so that it has the meaning of steadfast or patient (Anggen, 2012). Meanwhile, Ibn Qoyyim Al Jauziyyah (2010) explains the meaning of ash-shabr as prohibition or al-man'u, holding or al-habs and collecting or adh-dhammu.

Furthermore, Al Jauziyyah (2010) explains that patience is a noble character with which individuals are able to refrain from bad and inappropriate actions. Meanwhile, El Hafiz, Lila, Rozi, Ilham (2015) explain that patience is an active initial response in restraining emotions, thoughts, words, and actions that obey the rules for good purposes supported by optimism, never give up, the spirit of seeking information/knowledge, having the spirit to open alternative solutions, being consistent, and not easily complaining.

Patient individuals have the ability to refrain from complaining, always trying not to groan and hurt themselves (Al-Jauziyah, 2006). Individuals who have patience will be able to control themselves to be tough in facing problems, do not give up easily when facing difficult situations and are goal-oriented (Ong, Standiford, \& Deshpande, 2018). Efforts in realizing goals without complaining, being tough in facing difficult situations and controlling oneself not to do evil. In the context of education, one of the heinous acts is 
academic cheating which is often done by students.

The essence of the value of patience is to refrain from doing actions that keep you from achieving goals accompanied by obeying the rules (El Hafiz, Lila, Rozi, Ilham, 2015). This level of patience can be predicted as a control if the individual has self-efficacy which functions as a suppressor of the emergence of academic cheating behavior and determines the strength of the relationship between having self-efficacy and academic cheating. Therefore, the hypothesis proposed in this research is that the negative effect of self-efficacy on academic cheating is strengthened by the disposition of patience.

\section{Participants}

This research was conducted in high schools and universities in Jakarta. Participants who took part in this study amounted to 340 respondents, consisting of $38 \%$ women. Characteristics of respondents are students and college students aged 16 - 22 years with an average age of 19.3 years $(\mathrm{SD}=2.01)$. The technique used in sampling is accidental sampling.

\section{Measuring instrument}

Self-efficacy. The researcher used the General Self-Efficacy Scale compiled by Schwarzer \& Jerusalem (1995) based on the dimensions of self-efficacy by Albert Bandura to measure the self-efficacy variable. This scale consists of 10 statement items that are favorable with the type of Likert scale.

In each statement, four responses will be given with a score of 4 for respondents who chose Very Appropriate (VA), 3 for Appropriate (A), 2 for Disagree (D), and 1 for Strongly Disagree (SD). The General Self Efficacy Scale is spread over 10 items with 3 dimensions, namely level, Strength, and Generality dimensions, and all items are favourable. One example of an item statement on the Strength dimension is "I can always solve a difficult problem if I try hard.", and an example item from the level, namely "I believe that I can act well in unexpected situations". Internal consistency (Cronbach's alpha) obtained from the results of this study was $0.721(\alpha=.721)$

Patience. The patience variable was assessed using the patience scale compiled by El Hafiz Lila, Rozi, Ilham (2015). This scale consists of 20 items consisting of 5 items as distractors that are not analyzed, 8 items are favorable and 7 items are unfavorable using a Likert scale with 4 response categories, namely Very Appropriate (VA), Appropriate (A), Not Appropriate (NA). Strongly Incompatible (SI).

This scale consists of 6 aspects, namely optimistic, unyielding, consistent, not complaining, forgiving and seeking knowledge to find alternative solutions. Before responding to items, participants read the case first. An example of a case on this scale is "to achieve a good goal, I have failed more than once and the rules require to repeat the process from the beginning, on the last failure, my initial reaction...". While the example item in this case is "I need a long time to stabilize my emotions". Consistensy Internal (Cronbach's alpha) which obtained from this research result was $0,771(\alpha=.771)$.

Academic cheating. To measure academic cheating using an academic cheating scale which is based on the form of academic dishonesty proposed by Bashir and Bala (2018). This scale consists of 23 item statements with a Likert scale type. In each statement five responses will be given with a score of 1 for Never (N), 2 for Rarely (R), 3 for Sometimes (S), 4 for Often (O), and 5 for Always. (A). This scale has 6 dimensions, namely Cheating in Examination, Plagiarism, Outside Help, Prior Cheatin, Falsification, and Lying about Academic Assigments. An example of an item from the dimention of 
Chetaing In Examination is "When taking a test, I use signals (codes) to get answers from my friends". Internal consistency (Cronbach's alpha) which obtained from this result was $0.773(\alpha=.773)$.

\section{Data analysis}

This research has three variables consisting of the variable self efficacywhich functions as the Independent Variable (IV), the academic cheating variable as the Dependent Variable (DV) and the patience variable as the Moderator Variable (M). The moderator is a variable that determines the conditions in the relationship between IV and DV. Moderation contains an interaction effect that can change the effect (direction of the relationship) or reduce or enlarge the relationship between IV and DV. In the moderating statistical analysis, the researcher uses the PROCESS SPSS software which has been developed by Andrew F. Hayes (2013) with model 1 analysis.

\section{Results and Discussion}

\section{Results}

Demographic Data.

\begin{tabular}{lr}
\hline Variable & \multicolumn{1}{c}{ Score } \\
\hline Age (years) & $\begin{array}{r}19,3(2,01), \\
\text { range 16-22 }\end{array}$ \\
\hline Gender & \\
\hline Religius Group & $38 \%(\mathrm{~F})$ \& 62\% (M) \\
\hline Islam & $31,5 \%$ \\
\hline Education & $68,5 \%$ \\
\hline High School Degree & $47,91(4,53)$ \\
\hline Undergreduate & $28,71(3,83)$ \\
\hline Patience & $40,97(7,14)$ \\
\hline Self Efficacy & \\
\hline Academic Cheating
\end{tabular}

Moderator Role Patience is significant in strengthen the negative effect of self-efficacy on academic cheating.

The statistical analysis used in this research is the moderating model 1 developed by Andrew F. Hayes (2013) which aims to describe the moderating role of patience in the influence of self-efficacy in adolescents. The Independent Variable (IV) is patient, the Dependent Variable (DV) is academic cheating, while the variable Moderator symbolized by the letter $M$ is the variable of patience. The analysis of model 1 explains the moderating effect of patience on the relationship between self-efficacy and academic cheating. The strength of the relationship between self-efficacy and academic cheating can be seen from the level of patience possessed by individuals.

Based on the data obtained, it shows that the moderator role of patience has an interaction effect in the relationship between self-efficacy and academic cheating. The relationship between self-efficacy and academic cheating varies depending on the level of patience. Statistical analysis shows that there is a role of patience, as a moderator variable, which is significant in the relationship between self-efficacy and academic cheating with an interaction coefficient of-.0600and the value of $t$ is $3.4462(\mathrm{P}<0.001)$. therefore, the hypothesis can be accepted.

Strength of the Relationship between Selfefficacy with academic cheating depends on the level of patience possessed by the individual.

The effect of self-efficacy on decreasing of academic cheating, depends on the increasing patience variable. If adolescents have high patience, it will strengthen the negative effect of self-efficacy on academic cheating. Likewise, teenagers who have low patience will strengthen the negative effect of self-efficacy on academic cheating. The data is covered as follows: 
Tabel 1. The Level of Patience in the relationship between Self Efficacy with Academic Cheating

\begin{tabular}{|c|c|c|c|}
\hline \multirow[b]{2}{*}{ SE } & \multicolumn{3}{|c|}{ Patience } \\
\hline & $\begin{array}{c}\text { (1 SD } \\
\text { Below) }\end{array}$ & (Mean) & $\begin{array}{c}\text { (1 SD } \\
\text { Above) }\end{array}$ \\
\hline (1 SD Below) & 42,7031 & 44,0755 & 45,4479 \\
\hline (Mean) & 38,7767 & 41,1938 & 43,6108 \\
\hline $\begin{array}{l}\text { (1 SD } \\
\text { Above) }\end{array}$ & 34,8503 & 38,3120 & 41,7737 \\
\hline SE & $\begin{array}{c}\text { Low } \\
\text { Patience }\end{array}$ & $\begin{array}{c}\text { Moderate } \\
\text { Patience }\end{array}$ & $\begin{array}{c}\text { High } \\
\text { Patience }\end{array}$ \\
\hline SE Low & 42,7031 & 44,0755 & 45,4479 \\
\hline SE Medium & 38,7767 & 41,1938 & 43,6108 \\
\hline SE High & 34,8503 & 38,3120 & 41,7737 \\
\hline
\end{tabular}

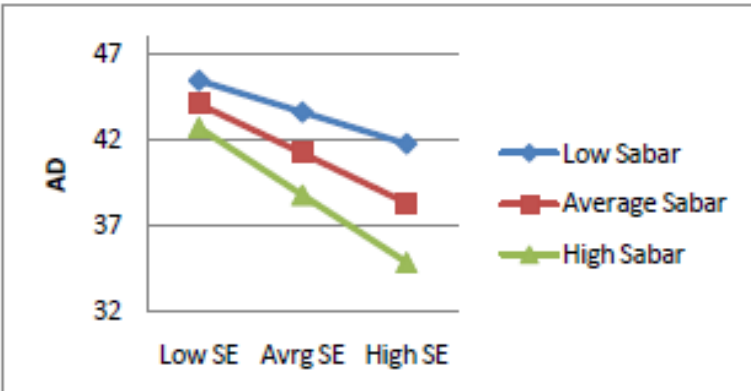

Picture 1 Graphic of Moderator Level of Patience on the Effect of Self-Efficacyi with Academic Cheating

Table 2. Effect Coefficient of Patience Level

\begin{tabular}{llcccc}
\hline \multirow{2}{*}{ Predictor } & \multirow{2}{*}{ Moderator } & \multicolumn{4}{c}{ Academic Cheating } \\
\cline { 3 - 6 } & & Affect & Std.err & T & Sign \\
\hline Self & Patience $_{\mathrm{High}}$ & $-1,02$ &, 105 & $-9,7$ & $<, 001$ \\
Efficacy & Patience $_{\text {Mean }}$ &,- 759 &, 077 & $-9,7$ & $<, 001$ \\
& Patience $_{\text {Low }}$ &,- 478 &, 115 & $-4,1$ & $<, 001$ \\
& & & & &
\end{tabular}

Based on the picture and data above, it shows that patience at all levels of patience, both low, medium and high has a significant negative effect on the strength of the relationship between self-efficacy and academic cheating. Statistical moderation analysis shows that patience can strengthen the relationship between self-efficacy and academic cheating to be different. Individuals with self-efficacy will produce academic cheating behavior depending on differences in the level of patience (M). The role of selfefficacy in the emergence of academic cheating behavior is greater when adolescents experience high patience, compared to adolescents who experience moderate and low patience. Although the level of patience both strengthens the role of self-efficacy against teenager academic cheating, but highest the person's patience and it will strengthen relation between self efficacy on academic cheating.

This research shows that self-efficacy can reduce the tendency of academic cheating in teenager depending on the level of patience. The higher the teenager's level of patience, the stronger the effect of self-efficacy in reducing a person's tendency to behave cheating. So, the strength of the relationship between selfefficacy and academic cheating depends on the individual's level of patience so that the proposed hypothesis can be accepted.

\section{Discussion}

The results showed that self-efficacy has a negative effect on academic cheating. This negative effect can suppress or reduce the tendency of academic cheating behavior. The results of this study are in line with research conducted by Fida et al (2018) by showing that self-efficacy regulation can suppress the emergence of academic cheating behavior in students. Not only as a factor suppressing the emergence of cheating behavior, self-efficacy also acts as a moderator in the relationship between academic achievement and cheating behavior (Murdock \& Anderman, 2016) and also acts as a mediator on the relationship between perceptions of emotional climate and family flexibility on the tendency of the emergence of academic cheating behavior (Murdock \& Anderman, 2016) Sabzian, Ghadampour \& Mirderikvand, 2018).

Individuals who have a tendency to previous academic cheating behavior have stress due to academic pressure to always succeed in tests and fear of failure or failure. Academic dishonesty behavior aims to improve academic performance so that this 
cheating behavior gets tolerance from individuals to do so. In addition to demands for increased academic performance, stress also has a role in the formation of academic cheating. Students and students who have high stress will have an impact on despair so as to encourage them to take risks by crossing the line of honesty which eventually commits academic cheating (Wideman, 2018).

Stress can be controlled properly if the individual has self-efficacy. Self-efficacy can be formed from cognitive control and the ability to cope with behavior (Schwarzer, 2014). If the individual has the ability to control cognition, then that ability will reframe thoughts to get out of stressful situations by growing the belief that the individual is able to change his behavior for the better. Conversely, when individuals have low cognitive control, they will be dragged into the situation and will experience despair to change their behavior for the better.

Self-efficacy also has an effect on appropriate behavior in an effort to improve academic performance without being accompanied by fraudulent behavior. Appropriate behaviors that come from selfefficacy are motivation, learning effects, selfregulation and academic achievement (Schunk \& Dibenedetto, 2016). With the formation of motivation that comes from self-efficacy, individuals will be encouraged to persevere and never give up when facing obstacles and obstacles and have resilience when facing difficulties.

Unyielding behavior that is formed from motivation is one of the important aspects in patient behavior (El Hafiz, Lila, Rozi, Ilham, 2015). The motivation to give birth to an unyielding attitude will give the spirit to continue learning and try to regulate oneself to get the best achievement. Therefore, when individuals have self-efficacy, they are predicted to have a great opportunity to achieve maximum performance (Fast et al,
2010). This self-efficacy effect will increase if the individual has the motivation and never gives up to get the best achievement without crossing the line of dishonesty. The individual's ability to refrain from dishonesty is at the core of the concept of patience, where patience is good attitude which make people can hold self from bad action (Al-Jauziyyah, 2010)

Individuals who have strong selfefficacy will see difficulties as challenges that can be overcome (Schunk \& Dibenedetto, 2016). They set challenging goals, stick to the commitments that have been set, strive to increase efforts when faced with failure and quickly recover when experiencing setbacks (Dogan, 2015). Efforts in achieving goals, commitment and persistent effort owned by individuals will strengthen the effect of selfefficacy on efforts to reduce fraudulent behavior in the academic field.

Researchers suspect that when individuals who have efforts to achieve goals, commitment and persistent effort will strengthen the effect on reducing academic cheating behavior if individuals have high patience. Efforts to achieve this cannot be separated from the individual's ability to regulate himself. Peterson and Seligman (2004) mention self-regulation as one of the three virtues that make up patience. Achieving goals, commitment and persistent effort are an integral part of the value of patience. This refers to the definition of patience that has been stated by El Hafiz, Lila, Rozi, Ilham (2015) that patience is an active initial response in holding back emotions, thoughts, words, and actions that obey the rules for good purposes supported by optimism, never give up,

Refraining from doing disgraceful acts, one of which is academic cheating, is the essence of patience (Al-Jauziyyah, 2010). Patience will give individuals the ability to get used to holding back despicable behavior through various aspects, namely emotions, 
thoughts or cognitions, words and deeds (El Hafiz, Lila, Rozi, Ilham, 2015). In the cognitive aspect, the ability of individuals who have good self-efficacy will have high cognitive control so that they are not trapped in cheating behavior. If this cognitive control is strengthened by the patient's ability to withstand disgraceful behavior, it will strengthen the effect of self-efficacy on efforts to reduce cheating behavior. It means, the effect of self-efficacy on academic cheating can be strengthened by the high value of patience possessed by individuals.

Another aspect of patience that can strengthen self-efficacy against academic cheating is not complaining. The determination to get out of stressful and stressful situations is often shown in the form of complaining behavior. The value of patience is what seeks to encourage individuals not to be trapped in stressful and stressful situations. Patient individuals will have the enthusiasm to open alternative solutions (El Hafiz, Lila, Rozi, Ilham, 2015) to overcome all life problems, pressures for demands and efforts to avoid despicable behavior.

The optimistic aspect which is included in the aspect of the value of patience is believed to strengthen the effect self-efficacy to reduce academic cheating behavior. High optimism in schools will strengthen students' perceptions that successful academic achievements will be appreciated and supported by various parties (Horner, Jordan, \& Brown, 2019). Despite having the same construct (Rand, 2017), research proves that there is a strong and significant relationship between self-efficacy with optimism (Feldman \& Kubota, 2015). The strong relationship between these variables cannot be separated from the similarity of characteristics between self-efficacy and optimism, which is goaldirected and future-oriented.

This research has a weakness in the use of a patience measuring instrument. Although the reliability of the patience measuring instrument obtained in this research is classified as having good reliability. However, the patience measuring instrument has a different internal consistency in the results of several previous researches. The recommendation for further research is to use a patience measuring instrument compiled by Brockhoff, K., Margolin, M., \& Weber, J. (2015). The Next researchers need to adapt the measuring instrument and test its validity and reliability.

The researcher would like to thank Ayu Indah Pratiwi for her help in distributing questionnaires to students.

\section{Conclusion}

This research aims to prove the moderating effect of patience on relationship between self-efficacy and academic cheating and also test the strength of the relationship between self-efficacy with academic cheatingwhich depends on the disposition of patience. The results of the moderation analysis lead the researcher to accept the proposed hypothesis, that the negative effectself-efficacy against academic cheating is moderated by the patience variable and the strength of the relationship between selfefficacy and academic cheating depends on the disposition of the patience variable. Negative effectSelf-efficacy against academic cheating will be stronger depending on the disposition of patience. Self-efficacy will be stronger in reducing academic cheating if individuals have high patience.

\section{References}

Alfons, M. (2019). 129 students cheated during UNBK, Kemendikbut: automatically scored zero. Downloaded from:https://news.detik.com /berita/d4539834/ May 13, 2019 
Al-jauziyyah, I.Q. (2010). Uddatush Shabirin. Dalam Firdaus. I (Eds,), Bekal untuk Orang-orang yang Sabar, Edisi Indonesia. Jakarta : Qisthi Press

Anggen, M. (2012). The miracle of sabar. Jakarta : Laskar Aksara

Bacon, A. M., McDaid, C., Williams, N., \& Corr, P. J. (2019). What motivates academic dishonesty in students? a reinforcement sensitivity theory explanation. British Journal of Educational Psychology. https://doi.org/10.1111/bjep.12269.

Bandura, A. (2010). Self-efficacy. The Corsini encyclopedia of psychology, 1-3. https://doi.org/10.1002/9780470 479216.corpsy0836

Bashir, H. dan Bala, R. (2018). Development and Validation of Academic Dishonesty Scale (ADS) : Presenting a Multidimensional Scale. International Journal of Instruction. Vol. 11 Nomor 2. pp. 57-54. 4. https://doi.org/10.12973/iji. 2018.1125

Brockhoff, K., Margolin, M., \& Weber, J. (2015). Towards empirically measuring patience. Universal Journal of Management, 3 (5), 169-178. DOI : 10.13189 /ujm.2015.030501

Dogan, U. (2015). Student engagement, academic self-efficacy, and academic motivation as predictors of academic performance. The Anthropologist, 20(3), 553-561..

https://doi.org/10.1080/09720073.2015.1 1891759

El Hafiz, S. Lila, P. Rozi, F. Ilham. (2015). Pergeseran Makna Sabar dalam Bahasa Indonesia. Jurnal Ilmiah Penelitian Psikologi: Kajian Empiris dan Non Empiris. Vol. 1 Nomor 1.Hal.33-38. JIPP. https://jipp.uhamka.ac.id/index.php/jipp /article/view/4

Fast, L. A., Lewis, J. L., Bryant, M. J., Bocian, K. A., Cardullo, R. A., Rettig, M., \& Hammond, K. A. (2010). Does math selfefficacy mediate the effect of the perceived classroom environment on standardized math test performance? Journal of Educational Psychology, 102(3), 729-740. https://doi.org /10.1037/a0018863

Feldman, D. B., \& Kubota, M. (2015). Hope, self-efficacy, optimism, and academic achievement: Distinguishing constructs and levels of specificity in predicting college grade-point average. Learning and Individual Differences, 37, 210-216. https://doi.org/10.1016/j.lindif.2014.11.0 22

Fida, R., Tramontano, C., Paciello, M., Ghezzi, V., \& Barbaranelli, C. (2018). Understanding The Interplay Among Regulatory Self-efficacy, Moral Disengagement, and Academic Cheating Behaviour During Vocational Education: A Three-Wave Study. Journal of Business Ethics, 153(3), 725-740. https://doi. org /10.1007 /s10551-016-3373-6

Giluk, T. L., \& Postlethwaite, B. E. (2015). Big Five personality and academic dishonesty: meta-analytic review. Personality and Individual Differences, 72, 59-67. https://doi.org/10.1016/j.paid. 2014. 08.027

Henning, M. A., Malpas, P., Manalo, E., Ram, S., Vijayakumar, V., \& Hawken, S. J. (2015). Ethical learning experiences and engagement in academic dishonesty: A study of Asian and European pharmacy and medical students in New Zealand. The Asia-Pacific Education Researcher, 24 (1),201-209. https://doi.org/10.1007/ s40299-014-0172-7. 
Iberahim, H., Hussein, N., Samat, N., Noordin, F., \& Daud, N. (2013). Academic dishonesty: why business students participate in these practices? ProcediaSocial and Behavioral Sciences, 90, 152156.https://doi.org/10.1016/j.sbspro.2013 .07 .076

Hayes, A. F. (2013). Introduction to mediation, moderation, and conditional process analysis: A regression-based approach. PsycNET. Guilford Press. https://psycnet.apa.org/record/201321121-000

Horner, M. V., Jordan, D. D., \& Brown, K. M. (2019). Academic Optimism. In Oxford Research Encyclopedia of Education. https://doi.org/10.1093/acrefore/9780190 264093.013.645

Miller, A. D., Murdock, T. B., \& Grotewiel, M. M. (2017). Addressing academic dishonesty among the highest achievers. Theory Into Practice, 56(2), 121-128. https://doi.org/10.1080/ 00405841.2017 .1283574

Murdock, T. B., \& Anderman, E. M. (2006). Motivational perspectives on student cheating: Toward an integrated model of academic dishonesty. Educational psychologist, 41(3), 129-145. https://www.researchgate.net/publication/ 233170024_Motivational_Perspectives_o n_Student_Cheating_Toward_an_Integra ted_Model_of_Academic_Dishonesty

Pan, M., Stiles, B. L., Tempelmeyer, T. C., \& Wong, N. (2019).A Cross-Cultural Exploration of Academic dishonesty: Current Challenges, Preventive Measures, and Future Directions. In Prevention and Detection of Academic Misconduct in Higher Education (pp. 63-82). IGI Global. DOI: 10. 4018/978-1-5225-7531-3.ch003
Peterson, C., \& Seligman, M. E. P. (2004). Character strengths and virtues: A handbook of classification. Washington, DC: American Psychological Association; New York: Oxford University Press.

Portnoy, J., Legee, K., Raine, A., Choy, O., \& Rudo-Hutt, A. S. (2019). Biosocial risk factors for academic dishonesty: Testing a new mediation model in young adults. Journal of Contemporary Criminal Justice, 35(1), https://doi.org/10.1177/10439862188105 90

Rand, K. L. (2017). Hope, Self-Efficacy, and Optimism. In The Oxford Handbook of Hope. DOI : 10.1093/oxfordhb/ 9780199399314. 013.4.

Schwarzer, R. \& Jerusale, M. (1995). Generalized Self-efficacy Scale. In J. Weinman, S. Wright \& M. Johnston. Measures in health psychology: A 62 user's portofolio. Causal and control beliefs (pp. 35-37). Winsor. England: Nfer-Nelson. https://doi.org/10.1177/ 109442810141004 .

Schnitker, S. A., Houltberg, B., Dyrness, W., $\&$ Redmond, N. (2017). The virtue of patience, spirituality, and suffering: Integrating lessons from positive psychology, psychology of religion, and Christian theology. Psychology of Religion and Spirituality, 9(3), 264. https://doi.org/10.1037/rel0000099

Schunk, D. H., \& Dibenedetto, M. K. (2016). Self-efficacy theory in education. Handbook of motivation at school, 2 , 34-54. https://www.routledgehandbooks.com/ doi/10.4324/9781315773384.ch3

Sabzian, S., Ghadampour, E., \& Mirderikvand, F. (2018). Providing a Causal Model for Perceptions of Emotional Climate and 
30| Psikis : Jurnal Psikologi Islami Vol. 7 No. 1 June 2021

Flexibility of Family with Academic Dishonesty: The Mediating Role of Academic Self-Efficacy. Quarterly Journal of Social Work, 7(3), 32-43. http:// socialworkmag. ir/article-1-292en.html

Wideman, M. (2018). Academic dishonesty in a school of nursing. https:// pdfs.semanticscholar.org/93d4/66d7d96 4a618b008d53612ed94131d818d50.pdf 